\title{
PENERAPAN TEKNIK DIGITAL PRINTING DAN BORDIR DENGAN INSPIRASI BANGUNAN HOTEL SAVOY HOMANN BANDUNG UNTUK PRODUK FESYEN
}

\author{
DEAnita Nabilla FERnanda, Widia Nur UTAmi Bastaman. \\ Received: 20 September 2019; Accepted: 23 Oktober 2019; Published: 5 November 2019 \\ Ed. 2019; 3 (1): $023-031$
}

\begin{abstract}
Buildings are one of the major inspiration frequently used on design theme for fashion industries. The purpose of this research is to raise the potential of a functional historical building in Bandung by the name of Hotel Savoy Homann. The visual potential of Hotel Savoy was used as inspiration for fashion products in the form of women's clothing. To represent the value of Hotel Savoy Homann, the writer choosed to use two varieties of surface design techniques which is digital printing and embroidery. This research carried out the qualitative method by doing field observation and collecting data from related literature studies. The execution was in the form of exploration sketches from images inspired by the exterior design of Hotel Savoy Homann. The outcome of this research is the application of digital printing and embroidery techniques on fashion products inspired by the building design of Hotel Savoy Homann Bandung whichprovides further alternative choices for fashion products in women's clothing and acquaint Hotel Savoy Homman to citizens of Bandung.
\end{abstract}

Keywords: building, Hotel Savoy Homann, digital printing, embroidery, fashion.

\section{PENDAHULUAN}

Perkembangan industri fesyen di Indonesia semakin meningkat, dengan adanya hal tersebut mempengaruhi perkembangan dalam penciptaan rancangan dan pengolahan pada produk fesyen yang terinspirasi dari berbagai hal. Bangunan merupakan salah satu inspirasi yang kerap digunakan dalam tema perancangan pada industri fesyen. Beberapa desainer lokal yang mengadaptasi unsur-unsur bangunan dalam tema karyanya yaitu Koleksi Didiet Maulana dengan tema "Press Play" pada event Jakarta Fashion Week 2018 yang terinspirasi oleh Pagoda Bali (FITRISARI, 2017), Raya by Soraya Karim dengan tema "The Lovely Taj Mahal" pada event Muslim Fashion Festival 2017 yang terinspirasi dari Bangunan Taj Mahal (NATASHI, 2017) dan Dini Pratiwi Irawati dengan tema "Siwargha" pada event Jakarta Fashion Week 2015 yang terinspirasi dari Candi Prambanan (TITI, 2014). Dengan adanya fenomena tersebut karena adanya kebutuhan pasar serta peluang di industri fesyen, penulis bermaksud untuk mengangkat potensi bangunan bersejarah yang ada di kota Bandung. Salah satu bangunan bersejarah di kota Bandung yang masih berfungsi hingga saat ini adalah Hotel Savoy Homann. Hotel Savoy berdasarkan Peraturan Daerah Kota Bandung No. 19 Tahun 2010 terdaftar dalam 100 bangunan cagar budaya. Hotel ini mengadopsi gaya arsitektur Streamline Modern Fungsional Art Deco Geometric karya arsitek asal Netherland Albert Frederik Aalbers dengan juru gambarnya R. de Waal (KUNTO, 1989), selain itu Hotel Savoy Homann memiliki peranan penting pada 
peristiwa Konferensi Asia Afrika tahun 1955 dan 2015 sebagai tempat persinggahan para delegasi negara (NOORMANSYAH, 2015). Berdasarkan paparan di atas peneliti menjadikan bangunan Hotel Savoy Homann sebagai inspirasi dalam perancangan karya yang akan dibuat dilatarbelakangi karena adanya potensi untuk mengembangkan Hotel Savoy Homann menjadi inspirasi suatu produk, khususnya pada produk fesyen. Oleh karena itu untuk merepresentasikan bangunan Hotel Savoy Homann peneliti memilih dua macam teknik rekalatar yaitu digital printing dan bordir. Digital printing dipilih karena teknik mudah direpetisi, dapat mengejar warna tertentu, kemudian proses produksi tergolong cepat serta kapasitas produksi bisa dalam jumlah banyak. Sedangkan bordir digunakan untuk mempertegas dan memberi tekstur timbul menggambarkan bagian garis horizontal maupun vertikal pada eksterior Hotel Savoy Homann. Dengan memahami hal tersebut diharapkan hasil dari penelitian ini menjadi alternatif pilihan variasi produk fesyen terhadap gaya hidup masyarakat saat ini, serta dapat mengenalkan Hotel Savoy Homann kepada masyarakat kota Bandung.

\section{METODE}

Metode yang digunakan dalam penelitian ini metode penelitian kualitatif. Metode penelitian ini dilakukan melalui pendekatan meliputi: (1) Studi Pustaka yaitu melakukan pengumpulan data dengan referensi kepustakaan dari buku, jurnal, laporan tugas akhir, dan internet untuk memperkuat argumen pada penelitian, maka penulis mengutip beberapa studi literatur yang terkait dengan penelitian. (2) Observasi yaitu mengumpulkan data melalui pengamatan secara langsung di Hotel Savoy Homann Bandung. (3) Wawancara yaitu melakukan wawancara secara langsung melalui public relation yang telah disediakan pihak Hotel Savoy Homann dan (4) Eksperimen yaitu melakukan eksplorasi dalam proses desain visual bentuk bangunan eksterior Hotel Savoy Homann menggunakan aplikasi pengolah grafis, serta penerapannya menggunakan teknik digital printing dan bordir.

\section{DASAR TEORI}

\section{A. Profil Hotel Savoy Homann}

Hotel Savoy Homann dibangun pada bulan Februari 1937 dan rampung pada akhir tahun 1939, kemudia Hotel Homann berganti nama menjadi Hotel Savoy Homann. Mengutip dari pernyataan SALMUN (1950) bangunan Hotel Savoy Homann awal mulanya beranjak dari rumah panggung bambu lalu dirombak menjadi gedung papan setengah tembok kemudian sejak tahun 1880 dikembangkan menjadi tembok utuh dan permanen, berlanggam arsitektur kolonial, dengan warna art deco.Gaya arsitektur Hotel Savoy Homann adalah Streamline Modern Fungsional Art Deco Geometrickarya arsitek asal Netherland Albert Frederik Aalbers dengan juru gambarnya R. de Waal (KUNTO, 1989).

\section{B. Ready to Wear}

Busana ready to wear adalah busana siap pakai, Proses pembuatan produk mode yang dibuat berdasarkan ukuran standar atau umum kemudian hasilnya dipasarkan sebagai produk siap pakai (TEE AT AL, 2015). Menurut John Hopkins dalam bukunya Fashion Design Complete Guidebahwa Ready to Wear diadaptasi dari istilah Perancis Pret-a-Porter, Ready to wear juga disebut off the Peg dari istilah British yang artinya sesuatu yang sudah siap dibuat. Busana siap pakai telah banyak digunakan dalam sektor retail fesyen dan terus meluas ke berbagai label pribadi dan merek grosir.

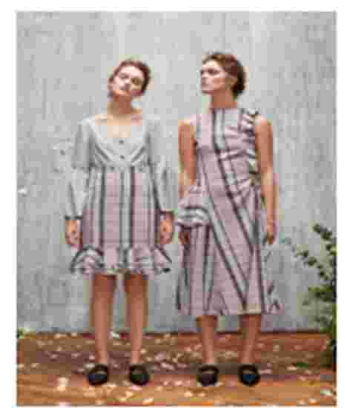

Gambar 1

Busana Ready to Wear Sumber: vogue.com, 2018 


\section{Rekalatar Tekstil}

Rekalatar tekstil adalah menciptakan, merancang, dan membuat sesuatu bentuk motif yang berbentuk dua dimensi diatas permukaan kain. Rekalatar umumnya diproses pada kain yang bewarna putih polos dengan menggoreskan berbagai macam motif dan warna sehingga kain tersebut memiliki keindahan, keunikan, dan kekhasan tersendiri (JULIANA, 2011).

1. Digital Printing: Teknik mencetak tinta diatas media berupa bahan atau media lain sesuai dengan bentuk yang dibutuhkaan, biasanya digital printing dilakukan oleh sebuah mesin print laser atau inkjet (DANIEL, 2017).

2. Bordir: Mengutip dari pernyataan dari Yuliarna dalam bukunya The Art of Embroidery Design istilah bordir identik dengan menyulam karena kata bordir diambil dari istilah Bahasa inggris embroidery (im broide) yang memiliki arti sulaman. Menurut SUHERSONO (2006) dalam bukunya bahwa bordir merupakan salah satu kerajinan ragam hias yang menitikberatkan pada keindahan dan kompisisi warna benang pada medium berbagai jenis kain, dengan alat bantu seperangkat mesin jahit (mesin jahit bordir) atau mesin bordir komputer.

\section{HASIL DAN PEMBAHASAN}

Potensi visual dengan inspirasi eksterior bangunan Hotel Savoy Homann dijadikan sebuah eksplorasi gambar yang merepresentasikan Hotel Savoy Homann. Bentuk bangunan Hotel Savoy Homann ini memiliki ciri khas secara visual dari unsur unsur eksterior bangunan Hotel Savoy Homann pada bagian detail lengkungan yang menyerupai ombak laut pada bangunan, jendela bundar yang bersusun 4 baris vertikal menyerupai jendela kapal laut, menara yang berada diatas lobby depan Hotel, aksen garis vertikal dan horizontal timbul dan bentuk bangunan yang simetris. Bentuk bangunan Hotel Savoy
Homann ini tidak bisa diubah ke dalam bentuk bangunan gaya arsitektur lain karena telah terdaftar menjadi bangunan cagar budaya sehingga harus dilestarikan. Dengan demikian eksperimen berupa eksplorasi gambar dibuat sesuai dari bentuk yang ada tanpa mengubah ciri khas dari bentuk asli bangunan Hotel Savoy Homann, serta menggunakan warna yang paling mendekati dari bangunan aslinya.

Pengolahan potensi visual eksterior Hotel Savoy Homann dengan membuat stilasi sketsa gambar manual kemudian ditracing menggunakan aplikasi pengolah grafis Corel Draw. Format warna RGB dipilih karena mendekati warna asli bangunannya. Hasil tracing direalisasikan menjadi sebuah eksplorasi gambar yang dikomposisikan dengan ukuran dan variasi bagian bentuk bangunan Hotel Savoy Homann hal ini bertujuan untuk mendapatkan hasil visual yang sesuai dengan konsep perancangan. Oleh karena itu untuk merepresentasikan hasil dari eksplorasi gambar tersebut teknik digital printing efektif aplikasikan pada bidang tekstil serta teknik bordir efektifdan juga optimal untuk mempertegas serta memberi tekstur timbul bagian garis horizontal maupun vertikal berulang bentuk bangunan Hotel Savoy Homann. Hasil dari eksplorasi gambar yang telah diaplikasikan teknik digital printing dan bordir, kemudian diterapkan pada sebuah produk fesyen berupa busana wanita dengan garis rancang busana tahun 1930-an kemudian dikombinasikan dengan desain busana modest wearsaat ini. Dengan demikian penelitian ini dibuat agar menjadi alternatif pilihan variasi produk fesyen terhadap gaya hidup masyarakat saat ini, serta dapat lebih mengenalkan Hotel Savoy Homann kepada masyarakat kota Bandung.

\section{A. Eksplorasi}

Pada tahap eksplorasi peneliti membuat eksplorasi gambar menggunakan aplikasi pengolah grafis dengan inspirasi bangunan Hotel Savoy Homann, kemudian mencoba 
eksplorasi gambar diaplikasikan menggunakan teknik digital printing dan bordir diatas permukaan kain untuk mengetahui hasil dari eksplorasi tersebut.

\section{Tabel Eksplorasi:}

\section{Gambar Visual Hotel Savoy Homann:}

1. Terlihat detail tembok beton dari arah samping dengan garis tegas persegi horizontal dengan tulisan Savoy Homann dan detail lengkungan berulang sebanyak 4 baris dengan detail garis streamline art deco pada bagian permukaannya.
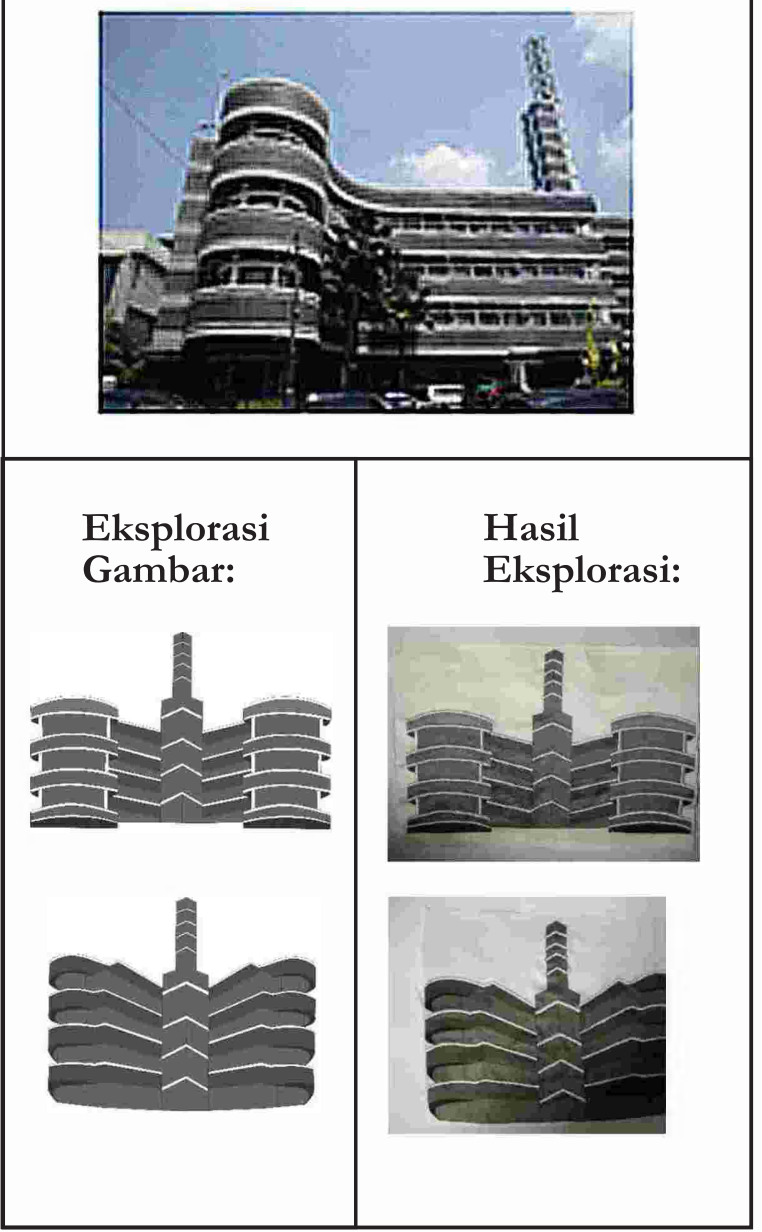

2. Tampak depan samping kiri bangunan Hotel Savoy Homan yang terdiri dari 4 baris kaca yang menyerupai kaca di kapal laut dengan detail garis streamline modern fungsional art deco geometric.
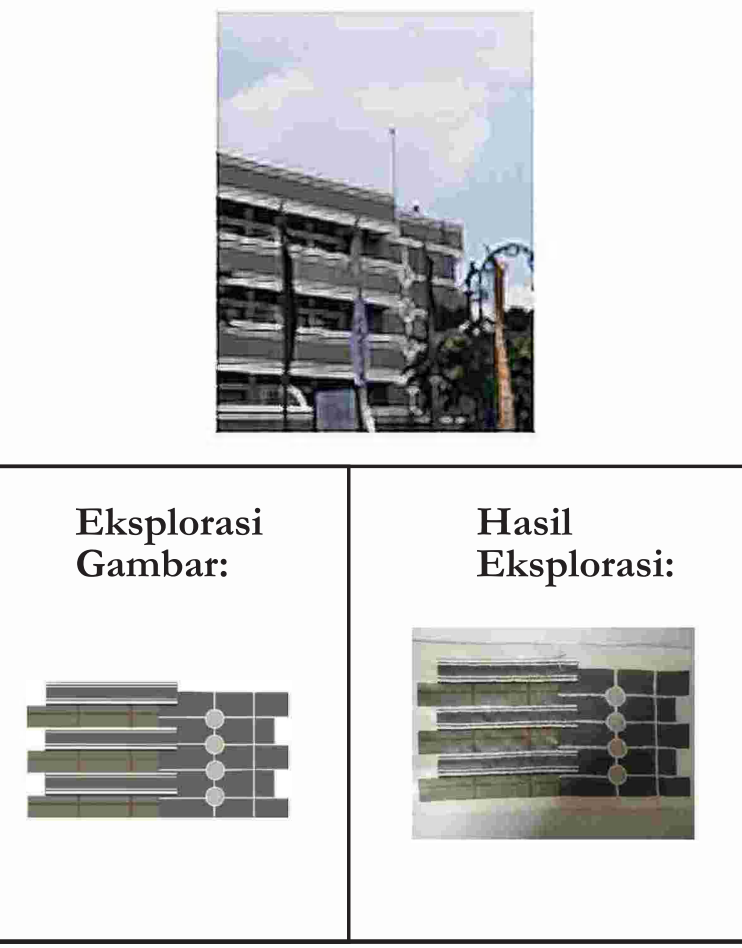

3. Menara bangunan Hotel Savoy Homann dengan detail garis streamline modern fungsional art deco geometric.

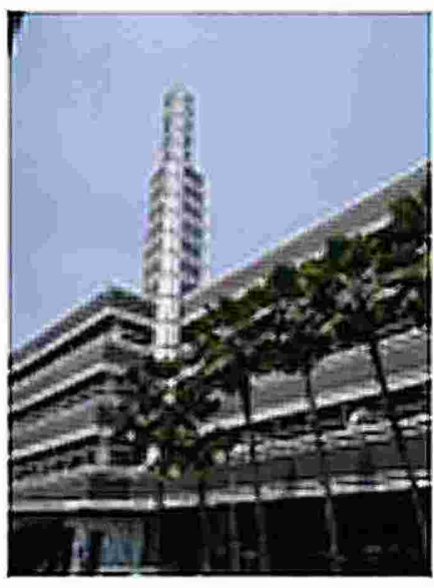




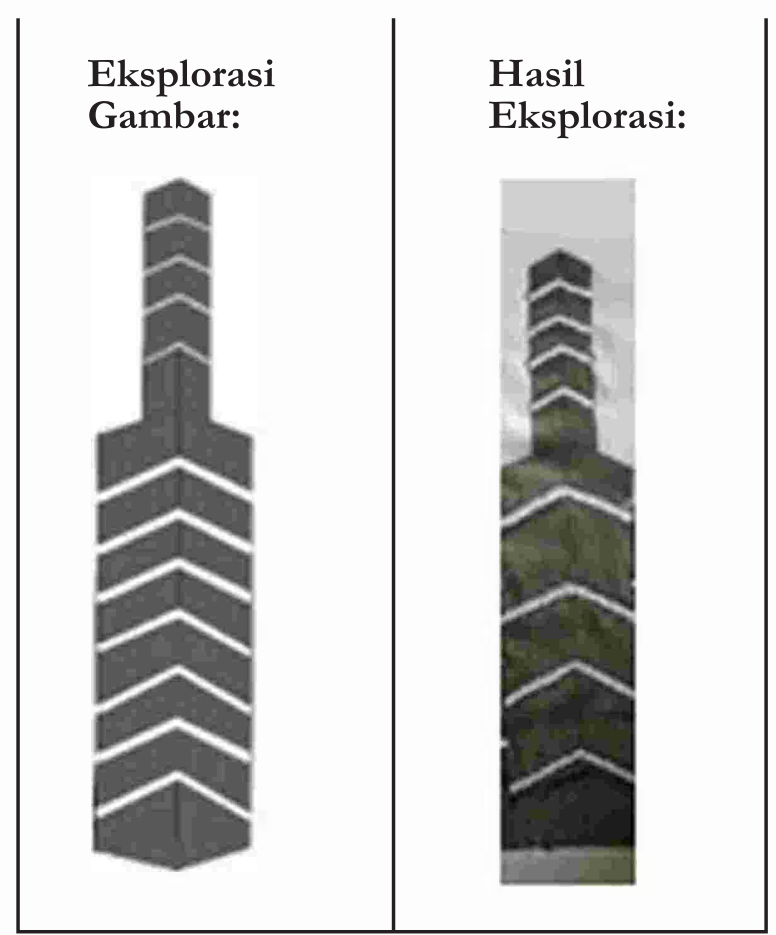

4. Unsur - unsur streamline art deco pada bagian lobby utama Hotel Savoy Homan dengan detail garis streamline modern fungsional art deco geometric.

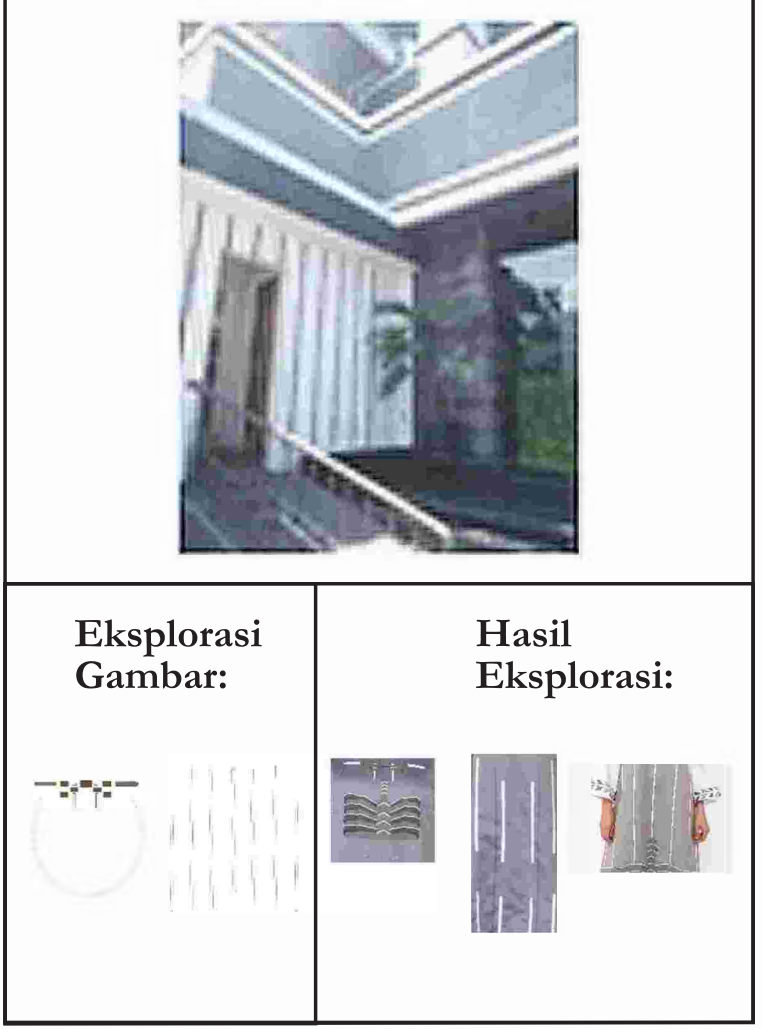

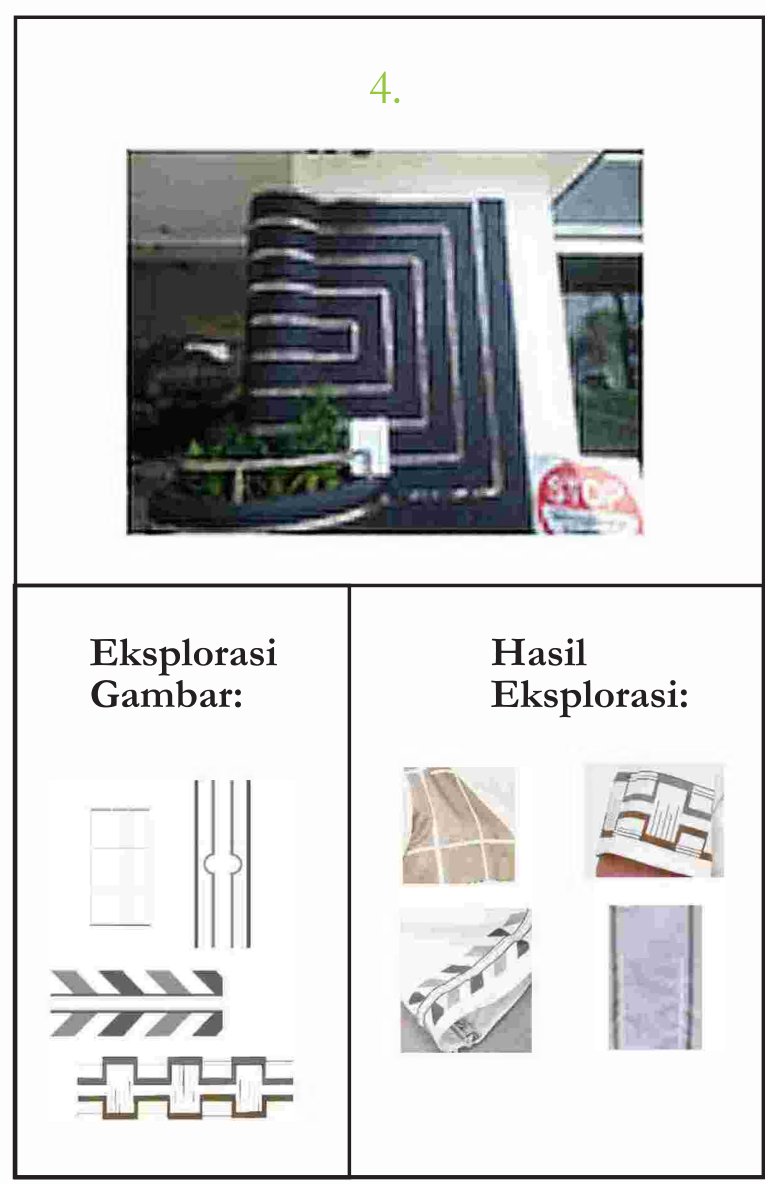

5. Tampak depan bangunan Hotel Savoy Homan terdiri dari bangunan lengkung berulang berbentuk kubistis, detail persegi panjang bangunan, yang didominasi detail garis Streamline Modern Fungsional Art Deco Geometric.

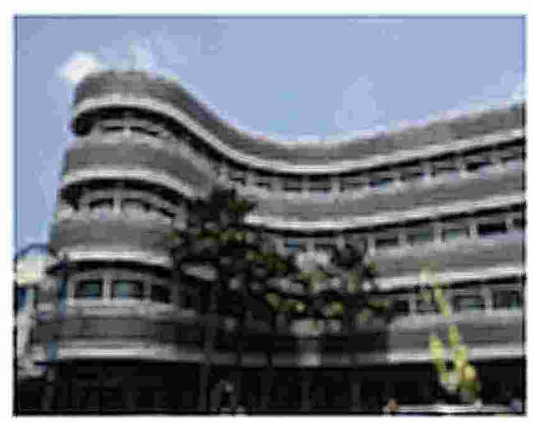




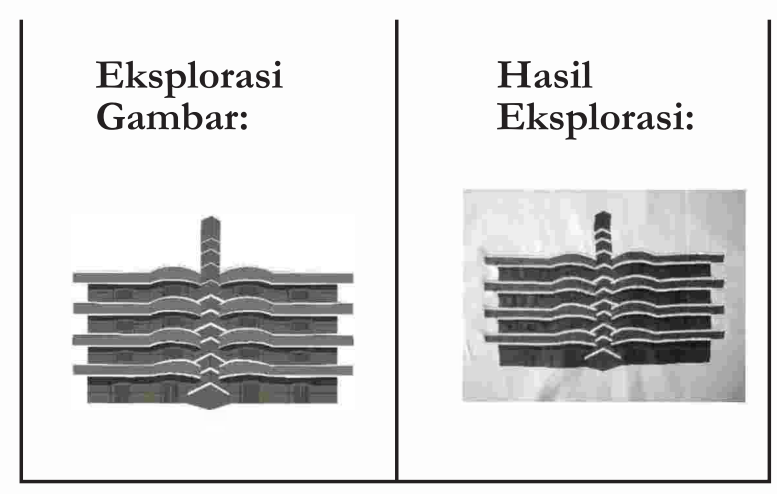

Sumber: Dokumentasi Pribadi, 2019.

Berdasarkan hasil eksplorasi lanjutan pada tabel diatas didapatkan bentuk-bentuk pengembangan dari unsur bangunan yang menjadi ciri khas bangunan Hotel Savoy dengan menggunakan warna yang tidak jauh beda dengan warna asli bangunan sehingga mencirikan identitas dari potensi visual bentuk Hotel Savoy Homann menggunakan warna yang tidak jauh beda dengan warna asli bangunan Hotel Savoy Homann. Berdasarkan keseluruhan eksplorasi gambar maka dipilih masing - masing hasil eksplorasi gambar yang paling memungkinkan untuk diaplikasikan pada busana untuk dilanjutkan pada proses produksi. Hasil eksplorasi lanjutan pada tabel diatas dapat disimpulkan jika kualitas vendor printing kain, format warna, dan kain yang digunakan sangat mempengaruhi hasil dari printing kain, selain itu karakteristik kain yang tebal efektif aplikasikan teknik bordir sehingga bordir yang dihasilkan tidak membuat permukaan kain menjadi mengkerut. Dari eksplorasi lanjutan tersebut untuk proses produksi produk akan digunakan format warna RGB pada eksplorasi gambar yang telah dibuat dan kain tafeta bridal karena efektif untuk diaplikasikan kedua teknik yang digunakan yaitu digital printing dan bordir.

\section{B. Konsep Perancangan}

Perancangan karya tugas akhir ini merupakan penciptaan rancangan dan pengolahan pada produk fesyen yang terinspirasi dari bangunan. Bangunan merupakan salah satu inspirasi yang kerap digunakan dalam tema perancangan pada industri fesyen. Salah satu bangunan bersejarah di kota Bandung yang masih berfungsi hingga saat ini dan mengadopsi gaya arsitektur Streamline Modern Fungsional Art Deco Geometric adalah Hotel Savoy Homann. Dalam perancangan karya tugas akhir ini dipilih dua macam teknik rekalatar yaitu teknik digital printing dan bordir untuk merepresentasikan serta mempertegas karakter dari visual Hotel Savoy Homann pada eksplorasi gambar yang telah dibuat. Peneliti membuat konsep image board yang merepresentasikan arah rancangan yang akan direalisasikan ke dalam bentuk busana wanita, dengan menggunakan image wanita yang menggunakan busana dengan bentuk siluet 1930an untuk mengejar bentuk dari eksplorasi gambar serta penempatan eksplorasi gambar pada busana wanita karena garis rancang gaya 1930an tidak banyak menggunakan potongan pola sehingga representasi dari eksplorasi gambar dapat terlihat secara maksimal selain itu rancangan desain busana dikombinasikan dengan karakter busana modest wear sehingga memberi kesan klasik, simple, tegas dan minimalis. Kemudian menggunakan detail yang terdiri dari unsur bangunan Hotel Savoy Homann seperti detail garis vertikal, horizontal serta detail lengkung dengan menggunakan pilihan warna yang sama dengan warna asli dari bangunan Hotel Savoy Homann.

Segmentasi pasar untuk hasil akhir dari penelitian ini yaitu: Wanita usia 25-35 tahun yang telah mulai meniti karir atau bekerja, berpenghasilan tetap. Memiliki profesi sebagai pekerja seni sehingga mengerti hal yang berkaitan dengan bidang seni kemudian profesi seperti pemain film professional, arsitek, interior desainer, influencer (fesyen, interior, arsitektur, dan komunikasi visual) dan wanita karir yang bekerja dibidang yang berhubungan dengan industri kreatif. 


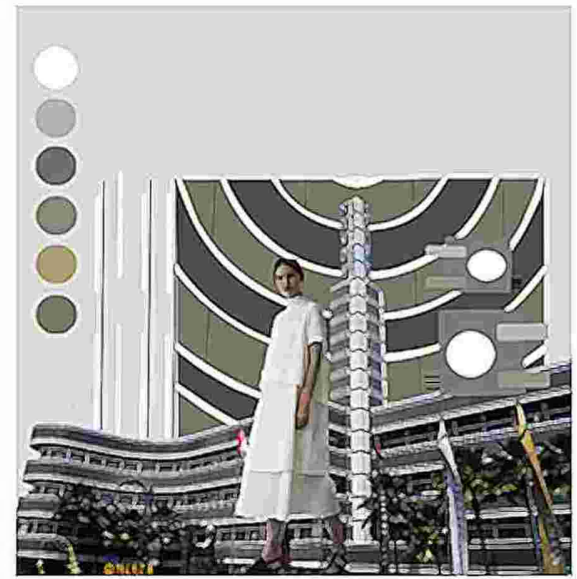

Gambar 2. Imageboard Sumber: Data Pribadi, 2019.

\section{Desain Produk}

Berdasarkan eksplorasi gambar yang diambil dari bagian ciri khas bangunan Hotel Savoy Homann serta unsur-unsur seperti detail garis dan lengkung, penulis membuat sketsa desain busana yang memiliki garis rancang 1930an dengan kombinasi desain busana modest wear serta penempatan eksplorasi gambar pada busana.

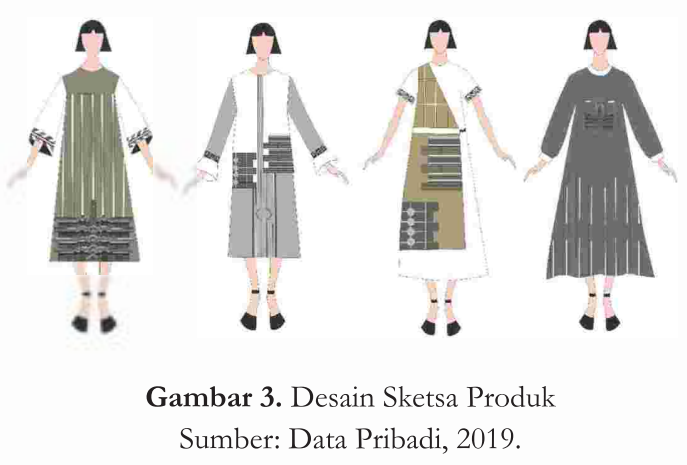

\section{Visualisasi Produk}

Visualisasi produk dapat dilihat pada gambar berikut yang merupakan hasil akhir dari penelitian tugas akhir ini.

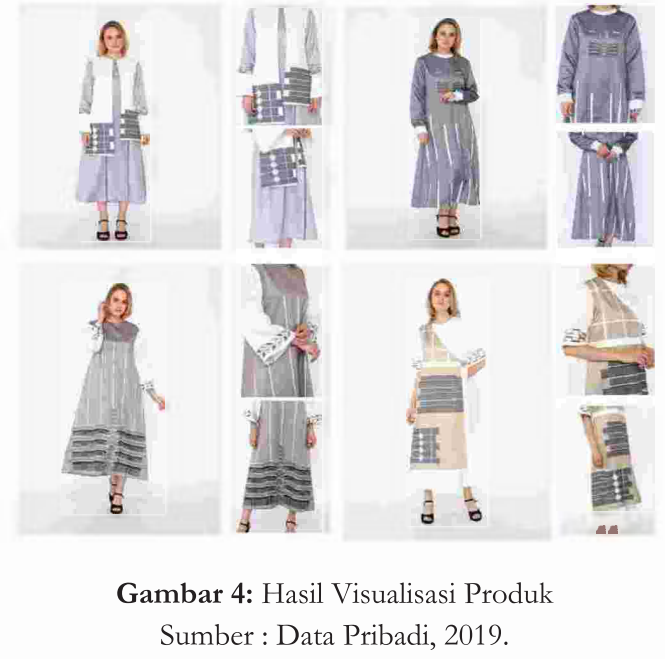

\section{KESIMPULAN}

Berdasarkan uraian yang telah dibahas dalam laporan tugas akhir yang berjudul "Penerapan Teknik Digital Printing Dan Bordir Dengan Inspirasi Bangunan Hotel Savoy Bandung Untuk Produk Fesyen" dapat disimpulkan bahwa:

1. Upaya penulis untuk merepresentasikan bentuk visual pada bangunan Hotel Savoy Homann Bandung sebagai inspirasi, dengan cara mengembangkan potensi visual bentuk bangunan eksterior Hotel Savoy Homann Bandung pada setiap bagian yang menjadi ciri khas meliputi bentuk bangunan yang simetris, bagian detail lengkungan berulang yang menyerupai ombak laut pada bangunan, jendela bundar yang bersusun 4 baris secara vertikal menyerupai jendela kapal laut, menara yang berada diatas lobby depan hotel serta unsur-unsur eksterior Hotel Savoy Homann di bagian lobby yang didominasi detail garis vertikal dan horizontal timbul. Dari hasil pengembangan dari potensi visual tersebut tersebut diwujudkan menjadi sebuah eksplorasi gambar kemudian diterapkan pada produk fesyen berupa busana wanita

2. Upaya penulis untuk mengolah potensi visual bangunan Hotel Savoy Homann yang dikembangkan dalam bentuk eksplorasi 
gambar menggunakan aplikasi pengolah grafis dengan menggunakan format warna RGB kemudian diaplikasikan menggunakan teknik digital sublimation printing dan bordir dengan material bahan kain tafeta bridal karena mengandung 100\% serat polyester, memiliki karakter sedikit kaku, tidak terlalu tebal dan tidak terlalu tipis sehingga efektif dan optimal diaplikasikan kedua teknik tersebut. Teknik digital printing menggambarkan visual dari hasil eksplorasi gambar pada permukaan kain, kemudian teknik bordir mempertegas serta memberi tekstur timbul pada detail garis horizontal maupun vertikal yang terdapat pada detail bangunan.

3. Upaya penulis untuk menerapkan hasil dari eksplorasi gambar yang telah diaplikasikan menggunakan teknik digital printing dan bordir berdasarkan pengolahan dari potensi visual Hotel Savoy Homann Bandung pada sebuah produk fesyen berupa busana wanita dengan garis rancang gaya busana 1930an yang dikombinasikan desain busana modest wear. Adanya hal tersebut dapat direalisasikan pada ke-empat produk busana yang dibuat berdasarkan penempatan hasil eksplorasi gambar yang diterapkan pada bagian depan busana tepatnya di bagian tengah sebagai point of interest yang menjadi titik utama tema yang diangkat sehingga terlihat representasi yang jelas secara langsung. Kemudian pada lengan busana diterapkan eksplorasi gambar berdasarkan unsur-unsur yang terdapat pada eksterior bangunan Hotel Savoy Homann seperti garis vertikal, horizontal, persegi, dan detail lengkung. Untuk warna yang digunakan yaitu warna abu muda, abu tua, coklat muda serta coklat tua, putih dan hitam menyesuaikan dengan warna asli yang terdapat pada bangunan Hotel Savoy Homann. Busana wanita yang dibuat oleh penulis merupakan busana dengan potongan siluet tahun 1930an yang tidak menggunakan banyak potongan pola pada busananya sehingga memudahkan penempatan hasil eksplorasi gambar pada pola digital. Dengan demikian dapat terlihat jelas representasi eksplorasi gambar visual dari bentuk bangunan Hotel Savoy Homann Bandung.

\section{DAFTAR PUSTAKA}

Kunto, Haryoto.

1989. Savoy Homann Persinggaban

Orang-Orang Penting.

Putu, DesaK.

2016. Teknik Dasar Bordir, 13-15.

\section{HASNA, RIFQAH.}

2015. Ekesplorasi Motif Majapabit Dan Motif Paisley Dengan Menggunakan Teknik. Digital Printing Serta Bordir Untuk Produk Fisyen, Tugas Akhir Program Sarjana, Universitas Telkom Bandung, 29 - 31.

FADHILAH, SALMA.

2017. Perancangan Busana Ready to Wear Menggunakan Teknik Engineered Print dengan Inspirasi Matif dari Icon Kota Bekasi, Tugas Akhir Program Sarjana, Universitas Telkom Bandung, 9-10.

DAMERIA, ANNE.

2013. Digital Printing Handbook: Panduan Dasar Digital Printing L arge Format/ Wide Format / Print on Demand / Digital Imaging / Digital Proofing.

\section{Ambarwati, MURni.}

2012. Men ggunakan Mesin Jabit Umum Dengan Mesin Bordir Pada Kain Katun Paris, Tugas Akhir Program Sarjana, Universitas Negeri Semarang, 3 - 5. 
BUDIYONO, DKK.

2008. Krija Tekstil Jilid 1 Kelas 10, 2 - 15.

ERNAWATI, DKK.

2008. Tata Busana Jilid $1-3$.

\section{G.J, Sumathi.}

2004. Elements of Fashion and Apparel, 10 - 11.

YULIARMA.

2016. The Art of Embroidery Design, 6-7.

\section{SuHERSONO, Hery.}

2006. Desain Bordir Motif Geometris, 6-7.

Greyzone Modest Fashion.

Data diperoleh melalui situs

https:/ / trendforecasting.id/greyzonesection/book-modest-fashion-4.

Diakses pada tanggal 20 Juni 2019.

\section{HOPKINS, JOHN.}

2012. Fashion Design Complete Guide.

section/book-modest-fashion-4.

Diakses pada tanggal 20 Juni 2019.

Goodreads. $A$ to Z Istilah Fashion.

Data diperoleh melalui s i tshttps://www.goodreads.com/boo k/show/17303728-a-to-z-istilah-f ashion. Diakses pada tanggal 04 April 2019.

Pengertian data dari Rencana Pengembangan Industri Mode Nasional.

Data diperoleh melalui situs http://indonesiakreatif.bekraf.go.id/ik pro/wpcontent/uploads/2015/07/Re ncana-Pengembangan-Mode-Nasional. Diakses pada tanggal 20 November 2018.
Pengertian Dan Jenis Digital Printing meru pakan data dari What Is Direct-To-Garment (Digital) T-Shirt Printing?,

Data diperoleh melalui situs https://www.planbprinting.com/ direct-togarment-printing/. Diakses pada tanggal 20 November 2018.

Perkembangan Tren Digital Printing meru pakan data dari Kapasitas Produksi Epson Bidik Industri Tekstil dan Digital Printing.

Data diperoleh melalui situs https://www.surabaya.tribunnews.com/20 18/11/21/dongkrak-kapasitas-produksi epson-bidik-industri-tekstil-dan-digitalprinting-jatim. Diakses pada tanggal 21 November 2018.

Savoy Homann Peranan Penting Pada Konferensi Asia A frika, merupakan data dari Konferensi Asia A frika 1955 dan 2015.

Data diperoleh melalui situs https:/ / tirto.id/konferensi-asia-af rika-8LV Nurul. Diakses pada tanggal

21 November 2018. 